\title{
Utilization of dimeric lignin model compounds by mixed bacterial cultures
}

\section{Pellinen, Jukka}

1984

Pellinen , J , Väisänen , E , Salkinoja-Salonen , M \& Brunow , G 1984 , ' Utilization of dimeric lignin model compounds by mixed bacterial cultures ' , Applied Microbiology and Biotechnology, vol. 20 , no. 1 , pp. 77-82 .

http://hdl.handle.net/10138/302209

Downloaded from Helda, University of Helsinki institutional repository.

This is an electronic reprint of the original article.

This reprint may differ from the original in pagination and typographic detail.

Please cite the original version. 


\title{
Utilization of dimeric lignin model compounds by mixed bacterial cultures
}

\author{
Jukka Pellinen ${ }^{1}$, Eino Väisänen ${ }^{1}$, Mirja Salkinoja-Salonen', and Gösta Brunow ${ }^{2}$ \\ ' Department of General Microbiology, University of Helsinki, Mannerheimintie 172, Helsinki 28 \\ ${ }^{2}$ Department of Chemistry, University of Helsinki, Vuorikatu 20, Helsinki 10, Finland
}

Summary. The degradation of dimeric phenylpropanoid lignin model compounds using mixed bacterial cultures was studied. The six model compounds contained the most common linkages of lignin: $\beta-O-4$, $\beta-\beta, \beta-5$, and $\beta-1$. The results indicate that it is possible to enrich bacteria which are able to degrade all these compounds. Bacteria were also able to use these dimers as the sole source of carbon for growth. In view of these results it seems probable that bacterial inability to degrade polymeric lignin is due to the physical properties such as the molecular size of lignin.

\section{Introduction}

Fungi are believed to be mainly responsible for returning of lignin into the carbon cycle while bacteria may be important for the degradation of small fragments arising from fungal degradation of lignin (Ander and Eriksson 1978; Crawford 1981). Several authors have reported partial degradation by bacteria of synthetic lignin models (DHP) (Trojanowski et al. 1977; Haider et al. 1978; Kaplan et al. 1980 ), in situ ${ }^{14} \mathrm{C}$-phenylalanine labeled lignin of poplar (Odier et al. 1981), douglas fir (Crawford 1978; Crawford and Sutherland 1979, 1980; Phelan et al. 1979) or spruce (Robinson and Crawford 1978) or ${ }^{14} \mathrm{C}$-labeled lignosulfonic acids (Haider and Trojanowski 1981).

At least two reasons could explain why bacteria degrade lignin only partially. Firstly, the permeability barrier of the bacterial cell membrane may exclude molecules of the size of lignin. Metabolism could hence occur only if effectuated by extracellular catalysts. Secondly, lignin may contain chemical bonds which cannot be cleaved by bacteria. Before

Offprint requests to: J. Pellinen taking on a study on the degradation of oligomeric lignin-born materials (industrial lignins) we studied the abilities of 11 mixed enrichment cultures of bacteria to utilize different types of dimeric phenylpropanoid model compounds. Degradation of the model compounds was determined by high performance liquid chromatography. The results are reported in this paper.

\section{Materials and methods}

Model compounds. The structures of compounds are presented in Fig. 1. 1-(3-methoxy-4-hydroxyphenyl)-2-(2-methoxyphenoxy)propane-1,3-diol (guaiacylglyccrol- $\beta$-guaiacyl ether, compound I), was synthesized using the procedure described by Miksche et al. (1966). 1-(3,4-dimethoxyphenyl)-2-(2-methoxyphenoxy)propalne-l,3-diol (verallylglyecrol- $\beta$-gualiacyl ether, compound II) was a gift from K. Lundquist, Chalmers University of Technology, Gothenburg. 1,2-bis(3-methoxy-4-hydroxyphenyl)-1,3-propanediol (compound III) was synthesized using a procedure described elsewhere (Ahvonen et al. 1983; Brunow et al. 1981). d-pinoresinol (compound IV) was from the same source as compound II and

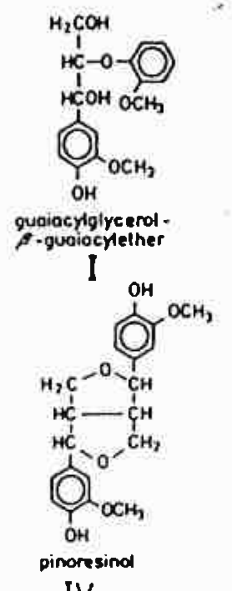

IV

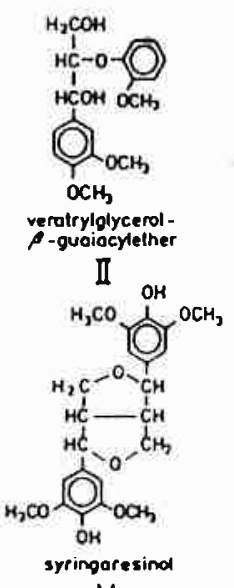

$\mathrm{V}$

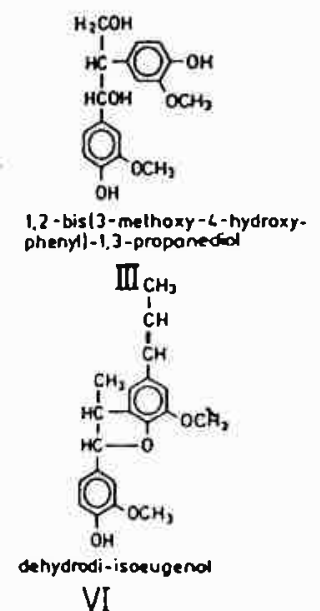

VI
Fig. 1. The dimeric phenylpropanoid compounds used in the present study 
d,l-syringaresinol (coumpound V) from T. Higuchi, synthesized by A. Kamaya, Institute of Wood Research, University of Kyoto. Dehydrodiisoeugenol (compound VI) was prepared from trans-isoeugenol according to Leopold (1950). The chemical identily and purity of each compound wiss verified with nuclealr

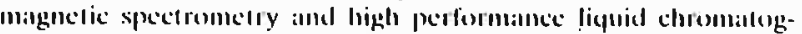
raphy.

Cultures. The 11 mixed cultures used in this study originated from inoculae collected in an area which was polluted by pulp and paper industry waste waters. The inoculae were enriched for 6 months at room temperature on ten different media composed of liquors from pulping industry: thermomechanical pulping waste water (1); $E_{1}$-stage spent liquor of oxygen bleaching (2); black liquor at $\mathrm{pH} 9$ (3) and 7.5 (4); $\mathrm{O}_{2}$-stage effluent of oxygen bleaching with bark chips at $\mathrm{pH} 9.5(5)$, at $\mathrm{pH} 9.5$ with $\mathrm{NH}_{4} \mathrm{Cl}(0.8 \mathrm{~g} / \mathrm{l}), \mathrm{K}_{2} \mathrm{HPO}_{4}$ $(1.2 \mathrm{~g} / \mathrm{l}), \mathrm{KH}_{2} \mathrm{PO}_{4}(0.8 \mathrm{~g} /) ; \mathrm{NaCl}(0.04 \mathrm{~g} / \mathrm{l})$, and $\mathrm{MgSO}_{4}(0.1 \mathrm{~g} / \mathrm{l})(6)$, and at $\mathrm{pH} 9.5$ without addition of nutrients (7). The oxygen bleaching liquor was ultrafiltered with a filter with a cut-off of $5,000 \mathrm{D}$ and the permeate and retentate were used in enrichments 8 and 9 , respectively, at $\mathrm{pH} 8$. Culture 10 was ohtained from a bioreactor described elsewhere (Salkinoja-Salonen et al. 1983). Culture number 11 was forest soil without further enrichment. Waste waters from thermomechanical pulping contained 3.5-10 $\mathrm{mg} \mathrm{N} / \mathrm{l}$ and $0.16-23 \mathrm{mg} \mathrm{P} / \mathrm{l}$, bleaching liquors $6-8 \mathrm{mg} \mathrm{N} / \mathrm{l}$ and $1.6-2.6 \mathrm{mg} \mathrm{P} / \mathrm{l}$, and black liquor ca. $14 \mathrm{mg} \mathrm{N} / 1$ and $\mathrm{ca}$. $2 \mathrm{mg}$ P/I.

Dimer degradation experimenis. The cultures were tested in the following way for their ability to utilize dimeric lignin model compounds as the sole source of carbon. A $50 \mu \mathrm{l}$ inoculum of a mixed culture was diluted in $1 \mathrm{ml}$ of a mineral salts medium containing $\left(\mathrm{NH}_{4}\right)_{2} \mathrm{SO}_{4}(1.0 \mathrm{mg}), \mathrm{KH}_{2} \mathrm{PO}_{4}(5.0 \mathrm{mg}), \mathrm{MgSO}_{4} \cdot 7$ $\mathrm{H}_{2} \mathrm{O}(0.1 \mathrm{mg}), \mathrm{FeSO}_{4} \cdot 7 \mathrm{H}_{2} \mathrm{O}(0.01 \mathrm{mg})$ per milliliter, supplemented with $5 \mu \mathrm{l}$ of a vitamin mixture (Sundman 1964), $1.0 \mu \mathrm{l}$ of a trace element mixture (Bauchop and Elsden 1960) and $0.3 \mathrm{mg}$ of compound I per milliliter of medium. The $\mathrm{pH}$ of the medium was adjusted to 7.0 . The cultures were incubated aerobically without agitation in $5-\mathrm{ml}$ tubes at $28^{\circ} \mathrm{C}$ and diluted after 7 days into a fresh medium ( $50 \mu \mathrm{l}$ of culturc into $1 \mathrm{ml}$ of the same medium). These cultures wcre used as inoculac for experiments with the dimeric phenylpropanoid compounds I-VI (Fig. 1).

Tixe effects of the antibiotics chloramphenicol and cycloheximide (Sigma, St. Louis, USA) $(0.10 \mathrm{mg} / \mathrm{ml})$ were examined using $1 \mathrm{ml}$ of the liquid medium as above with $0.15 \mathrm{mg} / \mathrm{ml}$ of compound $\mathrm{I}$.

An uninoculated control sample was prepared for each test incubation.

Measurement of bacterinl grow/h. Bacterial growth was estimaled by the increase in turbidity at $420 \mathrm{~mm}$ arter settlement of insoluble substrate and possible precipitates. Biomass was calculated from the turbidity as described in the literature (Koch 1981). The content of protein of the cultures grown on dimers could not be determined by the Lowry procedure because of interference by phenolic substrates and the quantity of biomass protein was too small for other methods of protein assay.

Chromatography. At the end of the incubation (7-12 days) $1 \mathrm{ml}$ of acetonitrile was added per milliliter of culture to dissolve unused substrate and possible reaction products. Insoluble solids (bacterial debris) were then removed by centrifugation. The acetonitrile extract was analyzed with a high performance liquid chromatograph (Micromeritics Instrument Corp., Norcross, Ga., USA) connected to a variable wavelength uv/vis-detector. Rad-Pak C18 ( 5 or $10 \mu \mathrm{m}$ ) columns were used in an RCM-100 compression module (Waters Associates Inc., Milford, Ma., USA). Acetonitrile and water mixtures containing $1 \%$ acetic were used as mobile phases.

\section{Results}

Tables 1 and 2 show how each of the cultures utilized the different model compounds. The percentage of degradalion was calculated from the difference in the

Table 1. Degradation of model compounds $I-V I^{a}$

\begin{tabular}{|c|c|c|c|c|c|c|}
\hline \multirow[t]{3}{*}{ Culture } & \multicolumn{6}{|c|}{ Compound } \\
\hline & I & II & III & IV & V & VI \\
\hline & \multicolumn{6}{|c|}{ Percent degraded of input } \\
\hline 1 & 100 & 17 & 81 & 100 & 42 & 0 \\
\hline 2 & 100 & 100 & 49 & 24 & 17 & 4 \\
\hline 3 & 100 & 100 & 94 & 80 & 62 & 0 \\
\hline 4 & 100 & 100 & 91 & 100 & 30 & 6 \\
\hline 5 & $1(x)$ & $I(x)$ & 96 & () & 47 & 34 \\
\hline 6 & 100 & 100 & 86 & 100 & 66 & 78 \\
\hline 7 & 100 & 100 & 79 & 100 & 44 & 0 \\
\hline 8 & 100 & 24 & 22 & 95 & 39 & 9 \\
\hline 9 & 100 & 53 & 20 & 0 & 38 & 42 \\
\hline 10 & 100 & 100 & 95 & 100 & 37 & 2 \\
\hline 11 & 62 & 6 & 0 & 8 & - & - \\
\hline $\begin{array}{l}\text { Average } \\
\text { degraded }\end{array}$ & 97 & 73 & 65 & 64 & 42 & 18 \\
\hline $\begin{array}{l}\text { Input of dimer } \\
(\mathrm{mg} / \mathrm{ml})\end{array}$ & 0.3 & 0.3 & 0.5 & 0.3 & 0.5 & 0.5 \\
\hline $\begin{array}{l}\text { Incubation } \\
\text { time (days) }\end{array}$ & 12 & 12 & 7 & 7 & 7 & 7 \\
\hline
\end{tabular}

a Degradation is expressed as $\left[\left(m_{0}-m_{x}\right) / m_{0}\right] \times 100 \%$, where $m_{0}=$ amount of dimer recovered from the uninoculated control sample, $m_{x}=$ remaining amount of dimer at the end of the incubation

$-=$ not determined

Table 2. Biomass yields for the cultures grown on lignin model dimers

\begin{tabular}{|c|c|c|c|c|c|}
\hline \multirow[t]{3}{*}{ Culture } & \multicolumn{5}{|c|}{ Compound } \\
\hline & I. & II & III & IV & $\mathrm{V}$ \\
\hline & \multicolumn{5}{|c|}{ Biomass ( $\mu \mathrm{g} / \mathrm{ml}$ dry weight) } \\
\hline 1 & 52.6 & 2.5 & 77.2 & 38.1 & 67.2 \\
\hline 2 & 87.7 & 35.5 & 12.5 & 0.0 & 51.0 \\
\hline 3 & 126.4 & 73.8 & 118.3 & 7.7 & 70.6 \\
\hline 4 & 96.0 & 50.4 & 39.2 & 46.8 & 47.7 \\
\hline 5 & - & 35.2 & 52.8 & 4.5 & 80.2 \\
\hline 6 & - & 76.7 & 32.9 & 49.1 & 133.2 \\
\hline 7 & 79.0 & 46.5 & 35.1 & 41.5 & 81.7 \\
\hline 8 & 52.0 & 10.1 & 22.6 & 30.8 & 47.7 \\
\hline 9 & - & 17.8 & 7.9 & 2.1 & 38.3 \\
\hline 10 & 86.0 & 79.0 & 121.2 & 60.5 & 61.6 \\
\hline 11 & - & 14.0 & - & 27.5 & 0.0 \\
\hline Average & 82.8 & 40.1 & 52.0 & 28.1 & 61.7 \\
\hline
\end{tabular}

Biomass yields were calculated from culture turbidities $\left(A_{420}\right)$ (measured against uninoculated blank) according to Koch (1981)

- $=$ not determined 


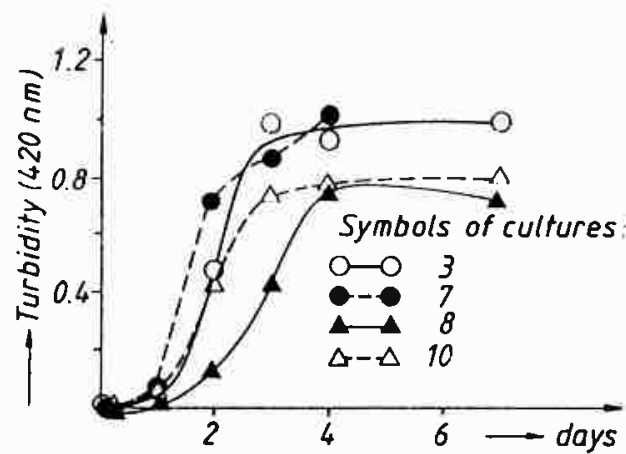

Fig. 2. Increase of culture turbidity during growth of cultures 3, 7, 8. and 10 on compound $\mathrm{I}(0.3 \mathrm{mg} / \mathrm{ml})$

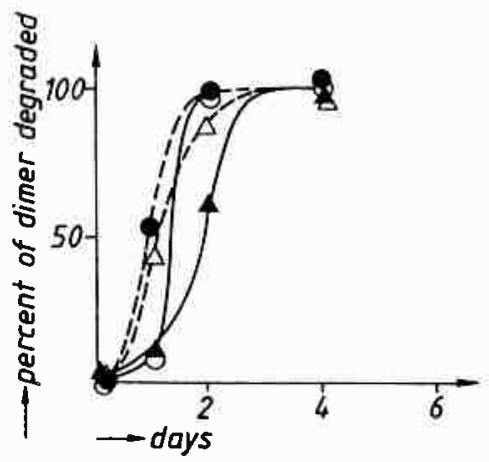

Fig. 3. Degradation of compound I by cultures $3,7,8$, and 10 . Symbols as in Fig. 2

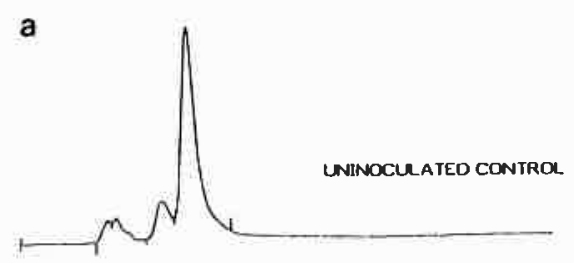

DICESTEO BY CUR TURE ?

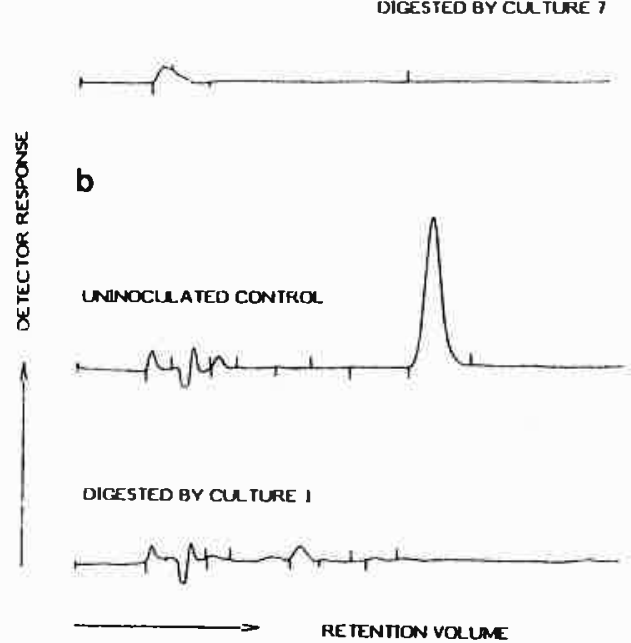

Fig. 4. Chromatographic analysis of the effect of bacterial digestion on compounds I (a) and IV (b) amount of dimer in incubated samples with and withour inoculum. Compounds with a $\beta-\mathrm{O}-4$ ether bond (I and II) were well degraded by the cultures. This was expected because cultures pregrown on compound I were used as inoculum and compounds I and II were closely related. However, the biomass yield was higher for compound I (average $82.8 \mu \mathrm{g} / \mathrm{ml}$ ) than for compound II (average $40.1 \mu \mathrm{g} / \mathrm{ml}$ ).

Figures 2 and 3 show that the maximum turbidity of the cultures was reached shortly after compound I had disappeared from the medium. The cultures grew to an optical density up to $\mathrm{A}_{420}=1.0$ (shown for compound $I$ in Fig. 2). This is high considering the low substrate input $(0.3 \mathrm{mg} / \mathrm{ml})$. Many cultures grown on the other compounds (II-VI) were similarly dense.

The cultures grew turbid in a few days and in many cases no uv-absorbing (254 $\mathrm{nm}$ ) compounds were left in the fully grown cultures, indicating disruption of aromatic rings. Examples of liquid chromatograms showing disappearance of the substrates are presented in Fig. 4.

Light microscopic and electron microscopic examination of the cultures showed that they were composed of bacteria exclusively. Table 3 shows how two antibiotics affected degradation of compound I. Chloramphenicol inhibited the degradation whereas cycloheximide had no effect. This confirmed the involvement of bacteria in the degradation; cycloheximide is known to affect eukaryotic cells and chloramphenicol prokaryotic cells.

The chromatograms showed that intermediate products were formed from compound III in several cultures. Two examples are presented in Fig. 5. Compound III used was pure erythro isomer. During incubation isomerization to threo isomer may have occurred. The peak area of the unincubated sample

Table 3. The effect of chloramphenicol and cycloheximide on the degradation of 1-(3-methoxy-4-hydroxyphenyl)-2-(2-methoxyphenoxy)-propane-1,3-diol (compound I) by cultures $3,4,7$, and 10

\begin{tabular}{llll}
\hline Culture & \multicolumn{3}{l}{$\begin{array}{l}\text { Percentage of degradation } \\
\text { a }\end{array}$} \\
\cline { 2 - 4 } & $\begin{array}{l}\text { No } \\
\text { antibiotic }\end{array}$ & $\begin{array}{l}\text { Chlor- } \\
\text { amphenicol }\end{array}$ & Cycloheximide $^{b}$ \\
\hline 3 & 100 & 32 & 100 \\
4 & 100 & 57 & 100 \\
7 & 100 & 41 & 100 \\
10 & 100 & 26 & 100 \\
Uninoculated & 0 & 0 & 0 \\
control & & &
\end{tabular}

\footnotetext{
a Calculated as in the Table 1 . Initial concentration of compound I was $0.15 \mathrm{mg} / \mathrm{ml}$ and incubation time 4 days

b Concentration $0.10 \mathrm{mg} / \mathrm{ml}$
} 


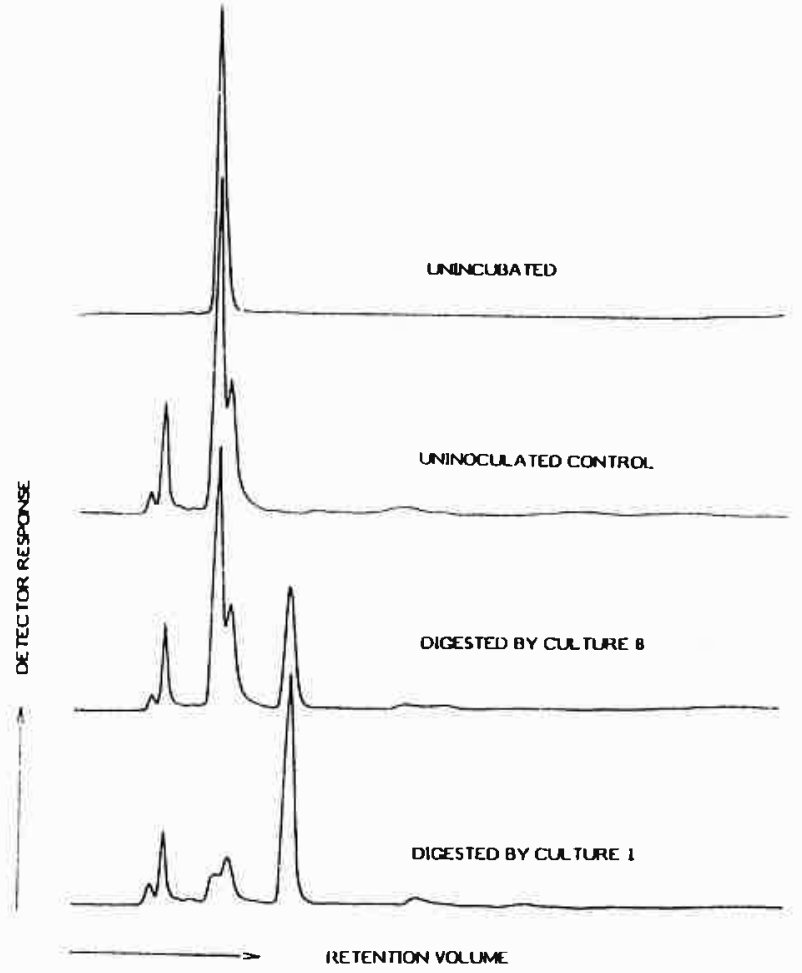

Fig. 5. Chromalogtaphic analysis of products from compound III after digestion by backeria

the combined area of the incubated control sample with the shoulder. The ratio of the peak areas (main peak: shoulder) in incubated control sample was $2: 1$.

Table 2 shows that biomass yield for compound III averaged $52.0 \mu \mathrm{g} / \mathrm{ml}$. The average biomass yields for compounds IV and $V$ were, 28.1 and $61.7 \mu \mathrm{g} / \mathrm{ml}$, respectively, despite their similar structures.

Compound $\mathrm{V}$ was metabolized somewhat less efficiently (average $42 \%$ ) than compound IV (average $64 \%$ ). A pink colour emerged from compound $V$ after a few days' incubation in some of the cultures. This may have been caused by accumulation of an intermediate product with quinonic structure (absorption maximum at $522 \mathrm{~nm}$ ). Degradation of the compound $\mathrm{V}$ may have halted because of toxicity of such a quinone to the bacteria.

Only three of the cultures degraded compound VI to a significant degree. The biomass values were not included in Table 2 because biomass assay was disturbed by the insoluble substrate.

None of the compounds was completely resistant against bacterial attack. Culture 6 metabolized each of the six model compounds and produced biomass using these compounds as the sole source of carbon and energy. This culture was enriched by using oxygen bleaching waste water at $\mathrm{pH} 9.5$ with addition of mineral salts.

\section{Discussion}

The most common linkages between the phenylpropanoid units of lignin are $\beta$-O-4-aryl ether, $\beta-1, \beta-\beta$, $\beta-5$, and 5-5 bonds (Lai and Sarkanen 1971). One way to study the biodegradability of lignin, is to use phenylpropanoid dimers linked to each other with one of these bonds. Bacterial degradation of such lignin models has been mostly studied with dimers containing the $\beta$-O-4 ether linkage (Trojanowski et al. 1970; Crawford et al. 1973; Fukuzumi and Katayama 1977; Katayama and Fukuzumi 1979b; Rast et al. 1980; Odier et al. 1982). Compounds of $\alpha, \beta$-diaryl, pinoresinol and phenylcoumaran types have also been studied (Katayama and Fukuzumi 1978, 1979a).

The results presented here show that the independently prepared cultures selected for growth on one type of dimer [guaiacylglycerol- $\beta$-guaiacyl ether (I)] also utilized other types of dimers. Dehydrodiisoeugenol (VI) differed from the other phenylpropanoid dimers in that it was much less degraded.

Inspection of the cultures by light microscopy and electron microscopy showed that they were composed of bacteria. Some occasional fungal hyphae in the primary cultures disappeared during continued culture with guaiacylglycerol- $\beta$-guaiacyl ether (compound I) as the carbon source. Absence of fungal growth probably reflects the inability of fungi to use ligninous materials as the sole source of carbon (Ander and Eriksson 1978; Kirk 1981).

Our results resemble those described by Fukuzumi and Katayama (1977) and Katayama and Fukuzumi (1978, 1979a, b) who had isolated Pseudomonas putida (strain FK2) on 5,5'-dehydrodivanillic acid and found that it was also capable of utilising several different structurally unrelated dimers. This coincidence may point at some type of genetic or metabolic linkage in the biodegradation of these dimeric lignín models.

The results (Table 2) show further that some cultures not only degraded the different phenylpropanoid dimers so that the original compound completely disappeared, but biomass was also formed. Although Katayama and Fukuzumi (1978, 1979a, b) did not specify growth yields, it is obvious from their data that their Pseudomonas strain could also use several dimers as the source of carbon and energy. According to Crawford et al. (1973) a Pseudomonas strain E-3 was able to use compound II as its only source of carbon and energy. A low biomass density $\left(10^{7}\right.$ cells $\left./ \mathrm{ml}\right)$ was reported by Odier et al. (1981) for bacteria grown on poplar lignin. In the other reports where the degradation of dimeric, oligomeric or polymeric lignin models was studied with bacteria, a supplementing carbon source was always used (Tro- 
janowski et al. 1977; Haicler et al. 1978; Robinson and Crawford 1978; Kaplan and Hartenstein 1980; Crawford et al. 1981), probably because no significant growth was otherwise obtained.

The inability of bacteria to propagate efficiently on polymeric lignin might therefore be caused by the molecular weight of lignin or inaccessibility of the substrate to extra cellular enzymes. If bacterial metabolism of benzenoid compounds is confined to intracellular mechanisms, large molecules which are not transported into the cell cannot be metabolized. The permeability barrier of gram negative bacteria has been shown to be around $600-1,300$ daltons for carbohydrates, polyethylene glycols, and peptides depending on the species (Payne and Gilvarg 1968; Nikaido and Nakae 198(0). The permeability for lignin has not been determined. However, treatments of bacterial cells with organic solvents which are known to increase the permeability of cell membrane do not necessarily lead to decreased enzyme activity (Fukui and Tanaka 1982). This opens perspectives towards a lignin-based biotechnical process, since polymeric lignin can be converted into soluble oligomeric material by several known procedures, such as auto-oxidation under pressure (Sarkanen 1975), catalytic hydrogenolysis (Harris et al. 1938), acidolysis (Lundquist and Lundgren 1972; Lundquist 1976), hydrolysis (Lora and Wayman 1980), electrochemical oxidation or reduction (Brewer et al. 1948; Chum and Osteryoung 1981) or steam hydrolysis (Nimz et al. 1983).

Acknowledgements. The authors thank R. Boeck and L. Lehtinen

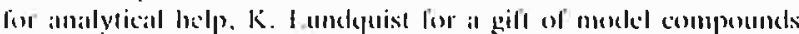
ind lor useful discussions with the aluhors. $Y$. Iliguchi and $A$. Kamaya for a gilt of model compounds, and ' 1 '. Ahvonen for help in the synthesis of model compounds. M.S.-S. was supported by the Academy of Finland.

\section{References}

Ahvonen T, Brunow G, Kristersson P, Lundquist K (1983) Stereoselective synthesis of lignin model compounds of $\beta-\mathrm{O}-4$ and $\beta-1$ types. Acta Chem Scand [B] 37: 845-\$49

Ander $\mathrm{P}$, Eriksson KE (1978) Lignin degradation and utilization by microorganisms. In: Bull $\mathrm{MJ}$ (ed) Progress in industrial microbiology, vol 14, Elsevier, Amsterdam, pp 1-58

Bauchop T, Elsden SR (1960) The growth of microorganisms in relation to their energy supply. I Gen Microbiol 2.3: $457-469$

Brewer CP, Cooke LM, Hibbert H (1948) Electrolytic oxidation of lignin. J Am Chem Soc 68:445-446

Brunow G. Koskinen L, Urpilainen P (1981) Reversal of direction of asymmelric induction in the horohydride reduction of two propiophenone derivalives using a polymer-bound reagent. Acta Chem Scand [B] 35:53-54

Chum HL, Osteryoung RA (1981) Survey of the electrochemistry of some biomass-derived compounds. SERI/TR-332-417. Report on contract No. EG-77-C-()1-4042, U.S. Department of Energy, USA
Crawlord DI. (197\$) Lignocellulose decomposition by selected Strepromyces strains. Appl Environ Microbiol 35: 1041-1045

Crawford DI. Sutherland JB (1979) The role of actinomycetes in the decomposition of lignocellulose. Dev Ind Microbiol 20): $|4.3-1.5|$

Crawlord DL. Sutherland JB (1980) Isolation and characterization of lignocellulose decomposing actinomyceles. In: Kirk TK, Iliguchi I. Chang HM (eds) Lignin hiodegralation: microbiology, chemistry and potential applications, vol II. CRC Press, West Palm Beach, pp 95-101

Crawford RL (1981) Lignin biodegradation and transformation. Wiley Interscience, New York Chichester. $154 \mathrm{p}$

Crawford RL. Crawlord DL, Dizikes GJ (1981) Catabolism of the lignin substructure model compound dehydrodivanillin by a lignin-clegrading Sircentomyeres. Arels Microbiol 129: 204-209

Crawford RL, Kirk TK, Harkin JM, McCoy E (1973) Bacterial cleavage of an arylglycerol- $\beta$-aryl ether bond. Appl Microbiol $25: 322-324$

Fukui S. Tanaka A (1982) Immobilized microbial cells. Ann Rey Microbiol 36: 145-172

Fukuzumi T, Katalyama Y (1977) Bacterial degrindation of dimer relating to structure of lignin. Mokuzai Gakkaishi $23: 214-215$

Haider K. Trojanowski J (1981) Mikrobieller Abbau von ${ }^{14} \mathrm{C}$ - und ${ }^{15} \mathrm{~S}$-markierten Ligninsulfonsäuren durch Pilze, Bakterien oder Mischkulturen. Holzforschung 35: 33-38

Haider K, Trojanowski J, Sundman V (1978) Screening for lignin degrading hacteria by means of ${ }^{14} \mathrm{C}$-labelled lignins. Arch Microbiol 119: 103- 106

Harris EE, D'Janni I. Adkins 11 (1938) Reaction of hardwood lignin with hydrogen. J $\wedge m$ (hem Soc $(1): 1407-1470$

Kaplan DL, Hartenstein R (1980) Decomposition of lignins by microorganisms. Soil Biol Biochem 12:65-75

Katayama Y, Fukuzumi T (1978) Bacterial degradation of dimers structurally related to lignin. II. Initial intermediate products from dehydrodiconiferyl alcohol by Pseudomonas putida. Mokuzai Gakkaishi 24: 643-649

Kalayama Y. Fukuzumi T (1979a) Bacterial degradalion of dimers structurally related to lignin. Ill. Metaloslism of a-veral-

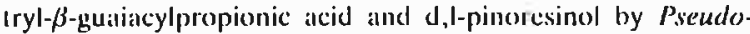
monas puida. Mokuzai Gakkaishi 25: 67-76

Katayama Y, Fukuzumi T (1979b) Bacterial degradation of dimers structurally related to lignin. IV Metabolism of guaiacylglyccrol- $\beta$-coniferyl ether by Pscudomonas pusida. Mokuzai Gakkaishi 25: 367-373

Kirk 'TK ( 1981$)$ 'loward elucidalion the mechanism of action of the ligninolytic system in Basidiomycetes. In: Hollacnder A (ed) Trends in the biology of fermentations for fuels and chemicals. Plenum Press, New York, pp 131-148

Koch AL (1981) Growth measurcment. In: Gerhard P, Murray RGE, Costilow RN, Nester EW, Wood WA. Krieg NR. Phillips GB (eds) Manual methods for general bacteriology. American Society for Microbiology, Washington DC, pp 179-207

Lai YZ. Sarkanen KV (1971) Isolation and structural studies. In: Sarkanen KV. Ludwig CH (eds) Lignins: Oecurrence, formation, structure and reaclions. Wilcy-lnterscience, New York, pp 165-240

Leopold B (1950) Aromatic keto- and hydroxypolyethers as lignin models. III. Acla Chem Scand 4: 1.523-15.37

L.ora JH, Wayman M (1980) Simulated autohydrolysis of aspen milled wood lignin in the presence of aromatic additives. Changes in molecular weight distribution. J Appl Polymer Science $25: 589-596$

Lundquist K (1976) Low-molecular weight lignin hydrolysis products. Applied Polymer Symposium 28: 1393-1407 
Lundquist K. Lundgren R (1972) Acid degradation of lignin. Part V11. The cleavage of ether bonds. Acta Chem Scand $26: 2005-2023$

Miksche (il: (iralyl J, liried-Malzka M (I)(6) Lur Symthese der beiden diastereomeren Formen des Guaiacylglycerin- $\beta$. (2-melhoxyphenyl)iitlers und des (indiilicylglycerrins. Actil Chem Scand 20: 1(1)38-1043

Nikaido H, Nakac T (198() The outer membrane of gram negative bacteria. Adv Microb Physiol 20: 163-250

Nimz HH, Tschirner U, Roth M (1983) Mild hydrolysis of $\beta-O-4$ linkages in lignin. Paper presented at the 1983 International Symposium on Wood and Pulping Chemistry, Tsukuba Science City, Japan, May 23-27

Odier E, Janin G, Monties B (1981) Poplar lignin decomposition by gram negative alerohic bacterial. Appl Environ Microbiol $41: 337-341$

Odier E, Rolando C, Monties B (1982) Catabolisme d'un modele moleculaire de type lignine. Proceedings of: Journées Internationales d'études du Groupe Polyphenols, Toulouse, France, September 29th-October 1st 1982

Payne JW. Gilwarg C (1968) Size restriction on peptide utilizattion in E. coli. J Biol Chem 243:6291-6294

Pellinen J, Väisänen E, Salkinoja-Salonen M, Brunow G (1983) Utilization of dimeric lignin model compounds by mixed bacterial cultures. Proceedings of: 1983 International Symposium on Wood and Pulping Chemistry, Tsukuba Science Cily, Japan, May 23-27 1983, vol 4:174-178

Phelan MB, Crawford DL, Pometto AL (1979) Isolation of lignocellulose-decomposing actinomycetes and degradation of specifically ${ }^{14} \mathrm{C}$-labeled lignocelluloses by six selected Streptomyces strains. Can J Microbiol 25: 1270-1276

Riast HG, Engelhardt G. Ziegler W. Witlnöler PR (1980) Biacterial degradation of model compounds lor lignin and chlorophenol derived lignin hound residucs. FEMS Microbiwlogy |1.ull| $x: 254) \cdots 20.3$

Robinson LE, Crawford RL (1978) Degradation of ${ }^{44}$ C-labeled lignins by Bacillus megaterium. FEMS Microbiol [Lell] $4: 301-302$

Salkinoja-Salonen MS, Hakulinen R, Valo R, Apajalahti J (1983) Biodegradation of recalcitrant organochlorine compounds in fixed film reactors. Wat Sci Tech 15:309-319

Sarkanen KV (1975) Wood lignins. In: Browning BL (ed) The chemistry of wood. Robert E. Krieger Publishing Co., Huntingdon New York, pp 24y-258

Sundman V (1964) A description of some lignanolytic soil bacteria and their ability to oxidize simple phenolic compounds. J Gen Microbiol 36: 171-188

Trojanowski J, Wojtas-Wasilewska M, Junosza-Wolska B (1970) The decomposition of veratrylglycerol- $\beta$-coniferyl ether by Agrobacterium sp. Acta Microbiologica Polonical [B] $2: 13-22$

Trojanowski J, Haider K, Sundman V (1977) Decomposition of ${ }^{14} \mathrm{C}$-labelled lignin and phenols by a Nocardia sp. Arch Microbiol 114:149-153

Received November 8, 1983 